
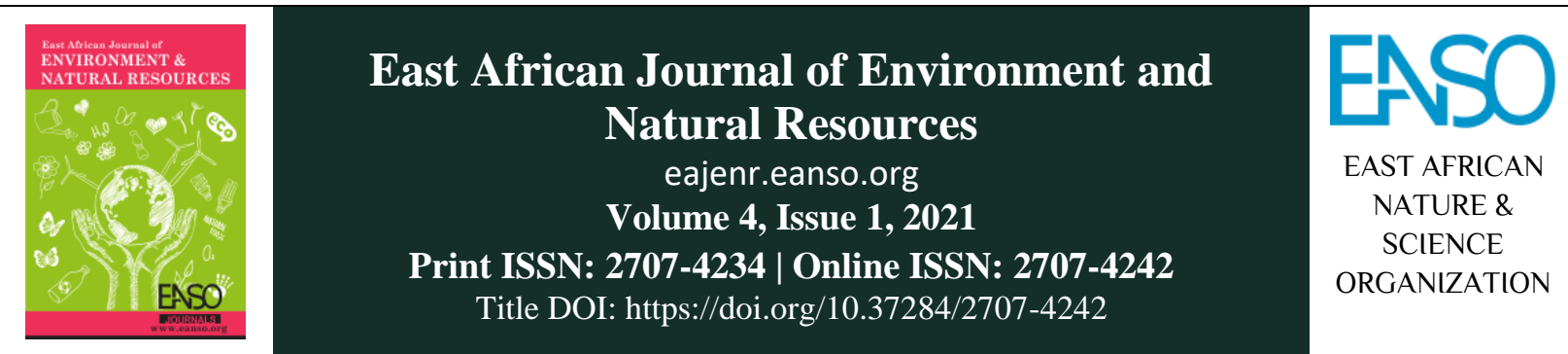

Original Article

\title{
Evaluation of two Non-Edible, Wild Indigenous Botswana Crops (Croton megalobotrys (Motsebi/Letsebi/Moshoole) and Ricinus communis (Mokhure)) as Potential Feedstocks for Petroleum and Cosmetic Industries.
}

\author{
Banyaladzi Doctor Paphane $1^{*}$, Bonang Nkoane ${ }^{2} \&$ Olayinka Adebisi Oyetunji $^{2}$ \\ ${ }^{1}$ Botswana University of Agriculture and Natural Resources, Private Bag 0027, Gaborone, Botswana. \\ ${ }^{2}$ University of Botswana, Private Bag UB 00704, Gaborone, Botswana. \\ *Correspondence email: docpapb@gmail.com.
}

Article DOI: https://doi.org/10.37284/eajenr.4.1.498

\section{Date Published: ABSTRACT}

07 December 2021

Keywords:

Croton

Megalobotrys,

Ricinus Communis,

Non-Edible Seed Oil,

Biodiesel,

Cosmetic Products,

Fatty Acids.
Croton megalobotrys and Ricinus cummunis plants produce high-quality nonedible seed oils at relatively high quantities of $39.65 \pm 0.06 \% \mathrm{w} / \mathrm{w}$ to $53.74 \pm$ $0.04 \% \mathrm{w} / \mathrm{w}$. The Iodine values of $85.97 \pm 1.62 \mathrm{~g} \mathrm{I} 2 / 100 \mathrm{~g}$ to $96.51 \pm 1.31 \mathrm{~g}$ $\mathrm{I} 2 / 100 \mathrm{~g}$; the low acid values of $0.96 \pm 0.05 \mathrm{mg} \mathrm{KOH} / \mathrm{g}$ to $5.31 \pm 0.76 \mathrm{mg}$ $\mathrm{KOH} / \mathrm{g}$; and high saponification values of $139.65 \pm 1.06 \mathrm{mg} \mathrm{KOH} / \mathrm{g}$ to $153.01 \pm$ $1.67 \mathrm{mg} \mathrm{KOH} / \mathrm{g}$ show that these seed oils can be useful feedstocks in the petroleum, soap, and cosmetics industries. GC-MS results revealed that R. cummunis seed oil is made up of eight (8) fatty acids with the bulk being ricinoleic acid at $81.51 \%$. Ricinoleic acid is the main fatty acid used in oleochemical industries. C. megalobotrys seed oil is made up of five (5) fatty acids, the most abundant being Linoleic acid which makes up $58.01 \%$ of the seed oil. The other two significant fatty acids in C. megalobotrys seed oil are palmitic and oleic acids at $19.51 \%$ and $18.37 \%$, respectively. These acids are important as starting materials in soap, cosmetic, and pharmaceutical industries. The fatty acids of the two seed oils absorb light at the ultraviolet region of the electromagnetic spectrum. This means that cosmetic products made from these seed oils will be effective in protecting the human skin against ultraviolet radiation. The FT-IR peaks for the two seed oils show that even though these seed oils are made up of different fatty acids, the active sites of their fatty acids are similar, implying that these seed oils can be used as starting materials in similar industries. 


\section{APA CITATION}

Paphane, B. D., Nkoane, B., \& Oyetunji, O. A. (2021). Evaluation of two Non-Edible, Wild Indigenous Botswana Crops (Croton megalobotrys (Motsebi/Letsebi/Moshoole) and Ricinus communis (Mokhure)) as Potential Feedstocks for Petroleum and Cosmetic Industries. East African Journal of Environment and Natural Resources, 4(1), 52-67. https://doi.org/10.37284/eajenr .4 .1 .498

\section{CHICAGO CITATION}

Paphane, Banyaladzi Doctor, Bonang Nkoane, \& Olayinka Adebisi Oyetunji. 2021. "Evaluation of two Non-Edible, Wild Indigenous Botswana Crops (Croton megalobotrys (Motsebi/Letsebi/Moshoole) and Ricinus communis (Mokhure)) as Potential Feedstocks for Petroleum and Cosmetic Industries". East African Journal of Environment and Natural Resources 4 (1), $52-67$. https://doi.org/10.37284/eajenr.4.1.498.

\section{HARVARD CITATION}

Paphane, B. D., Nkoane, B., \& Oyetunji, O. A. (2021) "Evaluation of two Non-Edible, Wild Indigenous Botswana Crops (Croton megalobotrys (Motsebi/Letsebi/Moshoole) and Ricinus communis (Mokhure)) as Potential Feedstocks for Petroleum and Cosmetic Industries", East African Journal of Environment and Natural Resources, 4(1), pp. 52-67. doi: 10.37284/eajenr.4.1.498.

\section{IEEE CITATION}

B. D. Paphane., B. Nkoane., \& O. A. Oyetunji, "Evaluation of two Non-Edible, Wild Indigenous Botswana Crops (Croton megalobotrys (Motsebi/Letsebi/Moshoole) and Ricinus communis (Mokhure)) as Potential Feedstocks for Petroleum and Cosmetic Industries", EAJENR, vol. 4, no. 1, pp. 52-67, Dec 2021.

\section{MLA CITATION}

Paphane, Banyaladzi Doctor, Bonang Nkoane, \& Olayinka Adebisi Oyetunji. "Evaluation of two Non-Edible, Wild Indigenous Botswana Crops (Croton megalobotrys (Motsebi/Letsebi/Moshoole) and Ricinus communis (Mokhure)) as Potential Feedstocks for Petroleum and Cosmetic Industries". East African Journal of Environment and Natural Resources, Vol. 4, no. 1, Sep 2021, pp. 52-67, doi:10.37284/eajenr.4.1.498.

\section{INTRODUCTION}

Non-edible seed-bearing plants have been seen as a good alternative to produce oil feedstock for many industries such as biodiesel, soap, cosmetics, and bio-lubricants industries (Heikal et al., 2017; Yaşar, 2020; Sarasan and Rangwala, 2014). Apart from being renewable and easy to grow, their use in these industries reduces the fight for food-based resources more especially in the Sub-Saharan Africa region, where the nutrition of most people is highly compromised (Shikha and Rita, 2012). The United Nations projects that, even though the world population will grow slowly compared to the past years, the world population will increase by 2 billion persons in the next 30 years, from 7.7 billion currently to 9.7 billion in 2050 (UN, 2017). Africa's share of the global population is projected to grow from $17 \%$ in 2020 to $26 \%$ in 2050 (World Population_Growth, 2021). This increase in African and world population means that there is need to look for new sources of feedstock that show potential for high oil yields and are resistant to most pests and crop diseases. In this research, we report the evaluation of seed oils of two plants that grow naturally in the wild in Botswana, Croton megalobotrys (known locally as Motsebi/Letsebi or
Moshoole tree) and Ricinus communis (known locally as Mokhure weed).

\section{Traditional Uses of C. megalobotrys}

C. megalobotrys is a medium-sized tree growing up to $15 \mathrm{~m}$ high and is known as the Fever berry tree in English (Langat et al., 2020). In Botswana, the tree is found in the Northwestern part of the country mainly along the large rivers in that area such as the Thamalakane River, Okavango River, and the pristine Okavango Delta. C. megalobotrys in these areas are known as Motsebi or Letsebi tree. The tree is also found in the central district along rivers in the Tswapong region where it is known as the Moshoole tree (Setshogo and Venter, 2003; Maroyi, 2017). The seeds and bark of the species have a considerable reputation among local communities as a remedy for fever or malaria (Maroyi, 2017). Table 1 shows the different uses of $C$. megalobotrys by locals in Botswana while Figure 1 shows a picture of C. megalobotrys tree at Malaka village, Central District of Botswana with its fruits and seeds. 
East African Journal of Environment and Natural Resources, Volume 4, Issue 1, 2021

Article DOI: https://doi.org/10.37284/eajenr.4.1.498

Table 1: Traditional uses of $C$. megalobotrys in Southern Africa

\begin{tabular}{lll}
\hline Use & Parts of the plant used & References \\
\hline Diarrhea of HIV patients & Bark decoction taken orally & Gatonye et al. 2016 \\
Fattening of babies & Root infusion taken orally & Maroyi 2017 \\
Fever & Seed taken orally & Venter and Venter 2007 \\
Laxative & Seed decoction taken orally & Hedberg and Staugard 1989 \\
Loss of appetite & Bark decoction taken orally & Hedberg and Staugard 1989 \\
Malaria & Bark, root, seed decoction & Gatonye et al 2016 \\
Stomach problems & Bark decoction taken orally & Hedberg and Staugard 1989 \\
Lumpy skin on Livestock & Leaf decoction applied on sores & Gatonye et al, 2016 \\
Wounds on Livestock & Bark and leaf decoction applied on wounds & $\begin{array}{l}\text { Gabalebatse 2013, Neelo } \\
\text { Construction timber and }\end{array}$ \\
firewood & Dry plant & Gabalebatse 2013, Neelo \\
Fish poison & Bark, leaves, and fruits & 2015 \\
Insecticides & Leaf decoction sprayed on arable land & Gatonye et al 2016 \\
\hline
\end{tabular}

Figure 1: Croton megalobotrys tree (1) at Malaka Village in Central Botswana in its natural habitat with its dried mature fruits (2) and seeds (3)
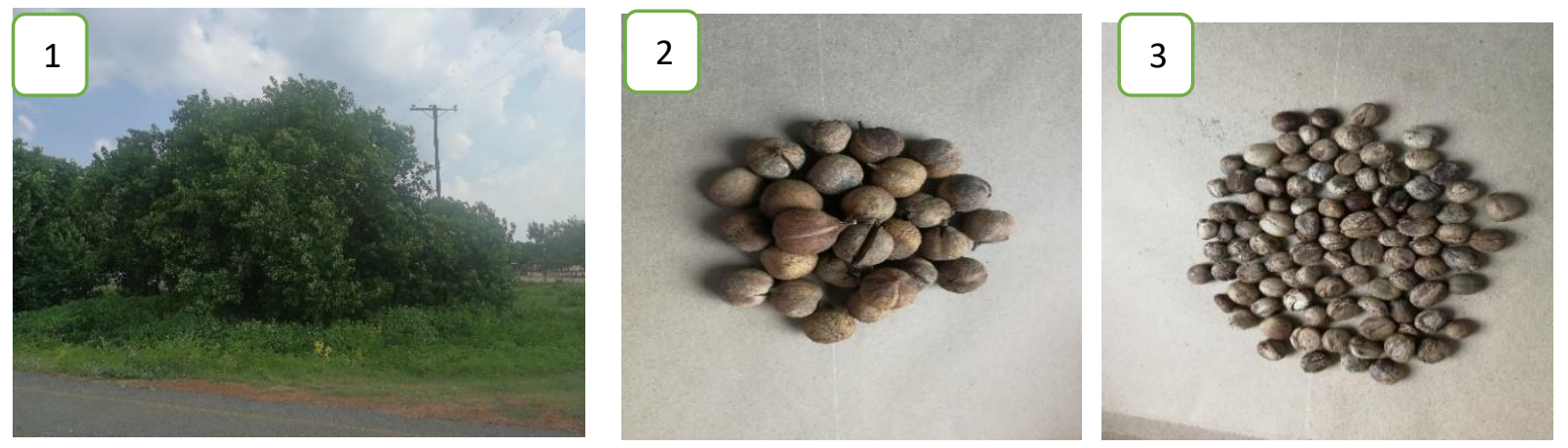

\section{Traditional Uses of $R$. communis}

Ricinus communis known locally as Mokhure shrub or weed, and internationally as castor oil plant, though it is believed to originate from wet tropics to subtropical dry regions, grows well in many areas and on different continents around the world. In warm regions, it can reach up to $8-10 \mathrm{~m}$ in height. It lives for many years and is perennial (Franke, 2019). In Botswana, like most parts of the world, $R$. communis is mostly found in waste places and is believed to be a densely growing weed (Marwat et al., 2017). It is known as a stubborn weed that grows in most arable farms and out-competes cultivated crops for water and nutrients. Therefore, farmers cut and dig it out whenever they come across it. This means that this plant is at a higher risk of extinction if nothing is done to protect it. Figure 2 shows a picture of $R$. Communis tree (1) at Tumasera village, Central District of Botswana with fruits and seeds (2) of this tree while Table 2 shows traditional uses of this tree. 
Figure 2: Ricinus communis tree with fruits (1) at Tumasera Village in Central Botswana in its natural habitat with its dried mature fruits and seeds (2)
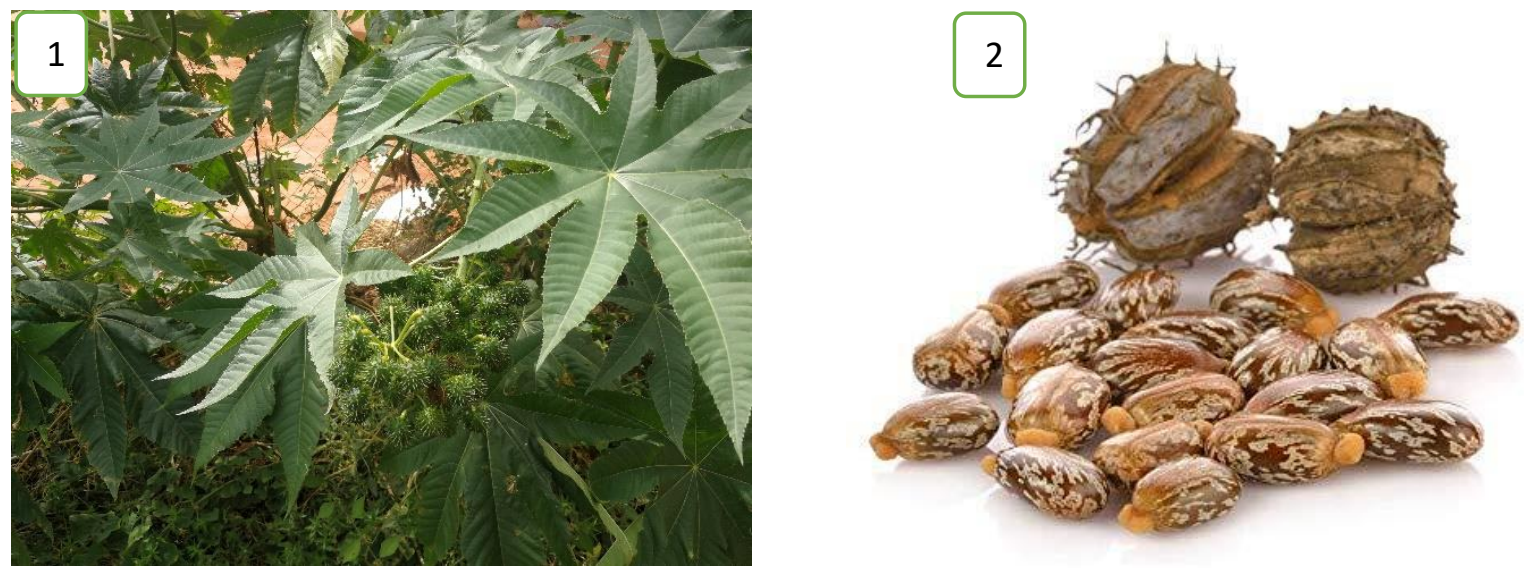

Table 2: Traditional uses of R. Communis in southern Africa including Botswana

\begin{tabular}{lll}
\hline Use & Parts of Plants Used & References \\
\hline Gonorrhea & Root infusion is drank & Chinsembu et al, 2019 \\
Diarrhoea of HIV patients & Root infusion is drank & Chinsembu et al, 2019 \\
Tuberculosis & Root infusion is drank & Chinsembu et al, 2019, Semenya \\
Skin Abscess & Dried Leave powder paste & and Maroyi, 2019 \\
Chronic Cough & Extract of boiled dried leaves is drank & Semenya and Maroyi, 2019 \\
\hline
\end{tabular}

\section{Oil from R. Communis and C. megalobotrys}

Ricinus communis oil (Castor oil) is becoming one of the most sought-after vegetable oils because of its rich properties and variety of end-uses. The world castor oil production between 2003 and 2013 has increased from 425 thousand tons to 681 thousand tons, displaying $4.82 \%$ annual growth rate (Anjani K., 2014). Castor oil has more than 700 industrial uses, including applications in medicines, coatings, cosmetics, lubricants, fuel additives, biopolymers, and biodiesel (Panhwar et al., 2016). Due to its unique chemical structure, castor oil is used widely in the industrial bio-chemical sector. It can be used as the starting material for producing a wide range of end-products such as biodiesel, lubricants and greases, coatings, soaps and detergents, surfactants, and oleo chemicals (Anjani K., 2014).
Solvent extraction of castor oil using $n$-hexane produces oil content varying from 34.6 to $56.6 \%$ (Panhwar et al., 2016). The composition of castor oil is mainly composed of fatty acids and neutral lipids (triglycerides). Majority of the triacyl glyceride (TAG) molecules found in castor oil contain three molecules of ricinoleic acid linked to a glycerol moiety (Mubofu, 2016, Yeboah et al., 2020). Ricinoleic acid (C18:1-OH), a monounsaturated fatty acid, is the major component present in castor oil (Yeboah et al., 2020). It has 18carbon chain and one double bond at the $12^{\text {th }}$ carbon with the molecular formula $\mathrm{C}_{18} \mathrm{H}_{34} \mathrm{O}_{3}$. Other fatty acids present in castor oil are, linoleic acid (C18:2), linolenic acid (C18:3), oleic acid (C18:1), palmitic acid (C16:1), and stearic acid (C18:0) (Omohu \& Omale, 2017). 
Figure 3: Structure of castor oil molecule

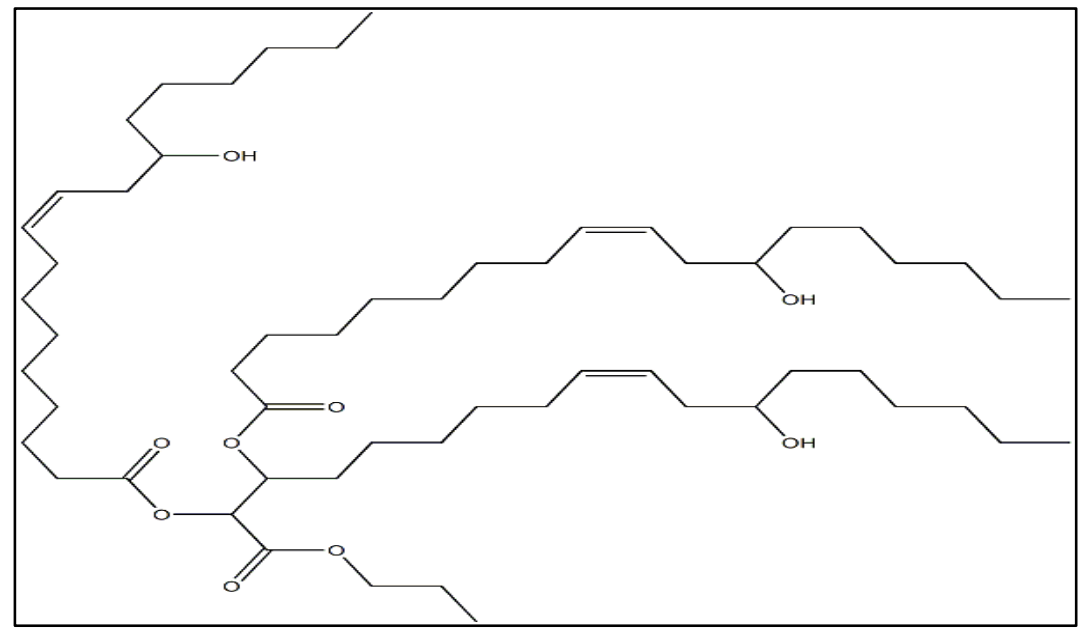

Source: (Yeboah et al., 2020).

Even though a lot of work has been done to unlock

value from $R$. cummunis seed oil, our literature search results showed that little to no work has been done on unlocking value from $C$ Megalobotrys oil hence this research.

\section{EXPERIMENTAL SECTION}

\section{Samples and Reagents}

Ricinus communis (Mokhure) wild fruits were collected from Gaborone city and Tumasera Village while Croton megalobotrys (Letsebi/Motsebi/Moshoole) wild fruits were collected from Gumare Village along the Okavango River and at Tumasera and Malaka Villages and transported in $50 \mathrm{Kg}$ nylon bags to the University of Botswana Analytical Chemistry Laboratory. The fruits were then sun-dried and seeds mechanically removed from the dried capsules by hand. The dry seed samples were decorticated and then milled to increase surface area using a Universal cutting mill (Fritsch cutting mill pulverisette number 15, Germany) without a sieve insert. Figure 4 shows the flow diagram for sample preparation of $C$. megalobotrys seeds from the dried fruit.

All solvents and chemicals were of analytical grade and were obtained from Merck (Germany), and Sigma-Aldrich (USA).

Figure 4: Flow diagram for Sample Preparation of Croton megalobotrys (Motsebi) seeds for Soxhlet Oil Extraction

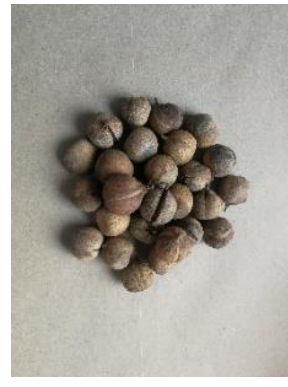

Seeds in Fruit Covers Oil Extraction
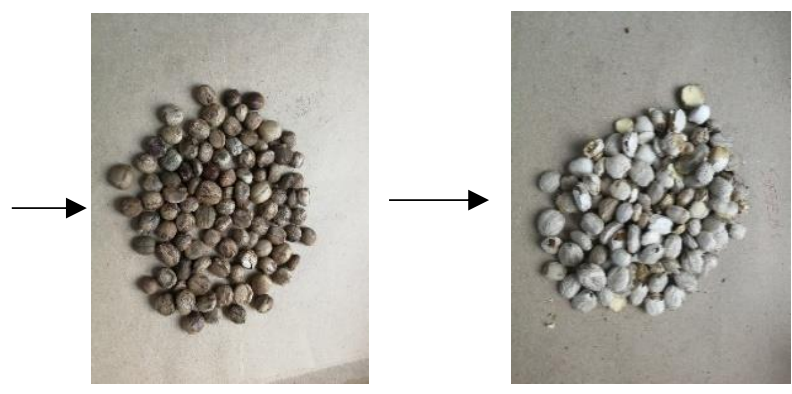

Undecorticated seeds

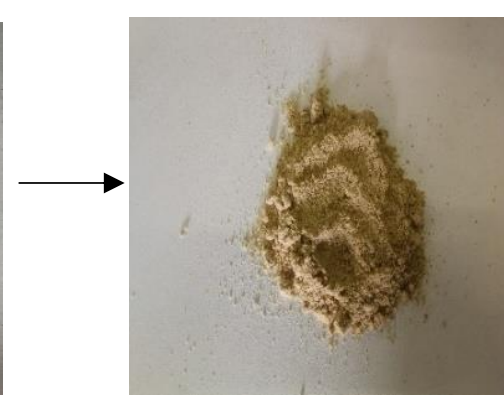

Decorticated Seeds

Seed Powder for 


\section{Oil Extraction}

The oil was extracted with the soxhlet extraction unit using the solvent extraction method in n-hexane (Bokhari et al., 2015). Oil extraction was carried out in two successive steps each of 6-hour duration to avoid underestimating the oil content. The solvent

Percentage oil extracted $=\frac{\text { Mass of oil extract }}{\text { Mass of Sample }} \times 100$
( $n$-hexane) was separated from the oil under suction using an R-215 Buchi Rotavapor. The percentage of solvent-free oil extracted was calculated from the equation:

Figure 5 shows the flow diagram of the Soxhlet oil extraction steps followed in this study.

Figure 5: Soxhlet extraction of Croton megalobotrys oil in n-hexane

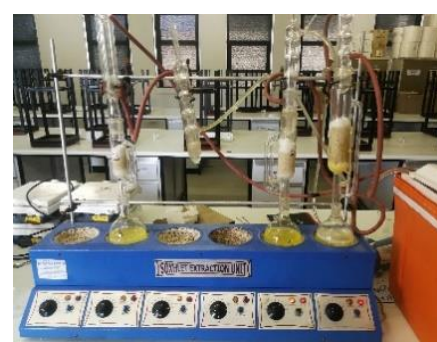

Soxhlet Seed Oil Extraction

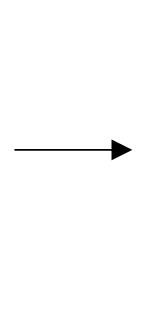

Rotary Evaporation of $n$-hexane

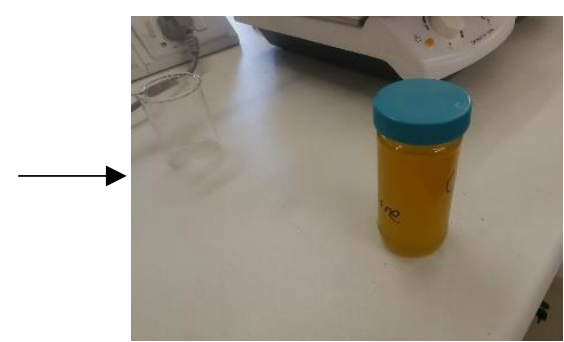

Croton megalobotrys seed oil

\section{Oil Quality Analysis}

\section{Physical Determinations}

The specific gravities of the seed oils were determined using a method described by the Association of Official Analytical Chemists (AOAC, 2006). The dynamic viscosity of expressed seed oils, in mPas.S, were measured at room temperature $\left(29{ }^{\circ} \mathrm{C}\right)$ using a Brookfield DV-E Viscometer (USA) equipped with a 0.2 spindle and 0.5 spindle for $C$. megalobotrys and $R$. cummunis oils respectively at $100 \mathrm{rpm}$ rotation rate. All determinations were carried out in triplicates. $\mathrm{pH}$ measurements were performed using ino-Lab 7110 WTW Lap-pH meter (UK).

\section{Physicochemical Properties of Seed Oils}

The acid value expressed in $\mathrm{mg}$ of $\mathrm{KOH} / \mathrm{g}$ of oil which is an indication of the oil's free fatty acid content was determined using the Association of Official Analytical Chemists (AOAC, 2006) method. The iodine value, which is a measure of the degree of unsaturation of the oil expressed as the number of centigrams of iodine absorbed per gram of oil was also determined as per AOAC, 2006 method. Saponification value, which is a measure of the soap content expressed in $\% \mathrm{~m} / \mathrm{m}$ of sodium oleate and Peroxide value, which expresses the state of oxidation or oxidative rancidity of the oil expressed in milliequivalents of active oxygen per kilogram of oil sample, were also determined as per the AOAC, 2006 methods.

\section{Fatty Acid Composition Using Gas Chromatography-Mass Spectroscopy (GC-MS)}

The fatty acids in seed oil samples were converted to fatty acid methyl esters (FAMEs) according to the method developed by Ichihara and Fukubayashi, 2009, and modified by Yuenyong et al. 2021, before analysis. $0.015 \mathrm{~g}$ of oil samples were mixed with $0.20 \mathrm{~mL}$ of toluene, $1.50 \mathrm{~mL}$ of methanol and 0.30 $\mathrm{mL}$ of $8.0 \%(\mathrm{w} / \mathrm{v})$ concentrated hydrochloric acid. The mixture was incubated at $100{ }^{\circ} \mathrm{C}$ for $5 \mathrm{~min}$. Then, $1.00 \mathrm{~mL}$ of hexane and $1.00 \mathrm{~mL}$ of water were added and mixed with the mixture. The hexane layer (upper layer) was separated for analysis. Fatty acid composition in oil samples was analyzed using a Gas Chromatography-Mass Spectrometer (GC-MS) 5975C inert XL EI/CI MSD with Triple-Axis Detector (Agilent, Polo Alto, CA). A HP-5MS capillary column $(30 \mathrm{~m} \times 0.25 \mathrm{~mm}, 0.25 \mu \mathrm{m})$ was 
used, and helium as carrier gas was flowed at $1 \mathrm{~mL}$ $\min ^{-1}$. The energy of electron impact was $70 \mathrm{eV}$. The inlet temperature was $280{ }^{\circ} \mathrm{C}$, and the injection volume was $1.0 \mu \mathrm{L}$ with a split ratio of $15: 1$. The column temperature was set at $165^{\circ} \mathrm{C}$, followed by a $4{ }^{\circ} \mathrm{C} \mathrm{min}-1$ oven temperature ramped to $290{ }^{\circ} \mathrm{C}$. The transfer line temperature was $290{ }^{\circ} \mathrm{C}$, and the ion-source temperatures were MS Quad $150{ }^{\circ} \mathrm{C}$, and MS source $230{ }^{\circ} \mathrm{C}$, respectively. The scanned mass range was $29-550 \mathrm{~m} / \mathrm{z}$, and the detector voltage was set at $1150 \mathrm{~V}$. Identification of the detected components was performed by matching their mass spectra with the reference spectra in NIST 98 Mass Spectral Library.

The peaks of the chromatogram were identified based on MS data analysis to determine the fatty acid content. The percentage of each fatty acid was determined by the area percentage (\%) of each peak, which later was employed in the determination of the predominant fatty acid of each sample. Where background interference was found in raw GC-MS data due to impure carrier gas and/or instrument noise, the background noise was deducted, and spectra smoothed before identifying the different fatty acids.

\section{Qualitative Analysis of the Oils Using UV-Vis and FT-IR spectrophotometry}

\section{$U V$-Vis analysis}

The UV-Vis molecular absorption spectra of the extracted oil samples were recorded using a computer-controlled Evolution 201 UV-Visible spectrophotometer (Thermo Scientific, Australia) with a quartz cuvette of $1 \mathrm{~cm}$ optical path. The software package (Insight, Thermo Scientific) was used for data acquisition and processing. Absorption spectra of the diluted $(1: 200, \mathrm{v} / \mathrm{v})$ solution of the oils in $n$-hexane was measured from 200 to $400 \mathrm{~nm}$ (Kružlicová et al., 008).

\section{Fourier Transform Infrared (FTIR) Spectrophotometric Analysis}

FTIR-8700 spectrometer (Shimadzu) equipped with deuterated triglycine sulfate detectors (DTGS) and a horizontal attenuated total reflectance (ATR) with Zinc Selenide ( $\mathrm{ZnSe}$ ) crystal was used to record Infrared spectra. The device is equipped with IR Pilot software that allows the setting of parameters of the spectrometer controls. IR spectra of the oil samples were collected over the spectral range $4000-400 \mathrm{~cm}^{-1}$ (Sejkorová et al., 2020).

\section{Statistical Analysis}

All quantitative measurements were done in triplicates, and the data are presented as the mean \pm standard deviation. Statistical analysis was done using one-way ANOVA with differences at $\mathrm{P}<0.05$ considered statistically significant.

\section{RESULTS AND DISCUSSIONS}

\section{Oil Extraction}

Table 3 shows results for physical parameters of $C$. megalobotrys and $R$. cummunis oils obtained from seeds collected from different places in Botswana. $R$. cummunis oil obtained is a pale-yellow oil while the $C$. megalobotrys is a yellowish-brown oil for all the seeds studied regardless of the location at which the seeds were collected. $R$. cummunis seed oil percentage yield shows that the oil obtained from Tumasera seeds were a bit higher at $44.87 \pm 0.03 \%$ than for oil obtained from Gaborone seeds at 39.65 $\pm 0.06 \%$. The differences in $\%$ yields might be due to rainfall distribution and different soil types in these areas. In Gaborone, the annual rainfall is normally lower than in Tumasera. The soil type in Gaborone is mainly loam while in Tumasera it is sandy loam which is good for growing fruit trees. The seed oil percentage yield from seeds collected in these two areas is consistent with the \% yield of cultivated $R$. cummunis plants around the world of around $40 \%$ to $50 \%$ (Yeboah et al., 2020; Anjani, 2014).

C. megalobotrys seed oil percentage yield shows that the oil obtained from Gumare seeds were a little bit higher at $53.74 \pm 0.04 \%$ than for oil obtained from Tumasera and Malaka seeds at $47.08 \pm 0.04 \%$ and $45.21 \pm 0.05 \%$, respectively. This might be because $C$. megalobotrys trees in Gumare village grow along the Okavango River which is a perennial river while those in Tumasera and Malaka grow along seasonal streams and rivers.

$R$. cummunis seed oil viscosities were $907 \pm 17$ $\mathrm{mPa} . \mathrm{s}$ and $987 \pm 18 \mathrm{mPa} . \mathrm{s}$, and specific gravities of $0.942 \pm 0.010$ and $0.926 \pm 0.012$, for the Gaborone and Tumasera oils, respectively. The high viscosity 
of castor oil ( $R$. cummunis seed-oil) is what makes it useful as a feedstock in many cosmetic and hair products, soap, and detergents, and lubrication industries but limited uses in biodiesel and biopetroleum industries (Kubala, 2018). The high viscosity of $R$. cummunis seed-oil compared to most edible seed oils is due to the long-chain and hydroxyl group of its dominant fatty acid, ricinoleic acid (Panhwar et al., 2016).

On the other hand, C. megalobotrys seed-oil exhibited low viscosities of $46.0 \pm 3.8,45.6 \pm 2.9$, $45.2 \pm 3.2 \mathrm{mPa}$.s and specific gravities of $0.894 \pm$
$0.010,0.896 \pm 0.003$ and $0.898 \pm 0.007$ for Gumare, Tumasera and Malaka oils, respectively. Oils which are low in viscosity are important in biodiesel and bio-petroleum industries. This is because it is easier to obtain high-quality biodiesel from them than from oils of high viscosities. The $\mathrm{pHs}$ of all oils studied were from $6.53 \pm 0.05$ to $6.89 \pm 0.08$ (Table 3 ) which means that all these oils fall within the neutral range of the $\mathrm{pH}$ scale. Therefore, whether they are used as feedstock for cosmetic or petroleum products they will not be harmful to the human skin or mechanical/vehicle engine parts.

Table 3: Physical Parameters of $C$. megalobotrys and $R$. cummunis oils obtained from seeds collected at different places in Botswana

\begin{tabular}{|c|c|c|c|c|c|}
\hline $\begin{array}{l}\text { Oil Name and places seeds } \\
\text { were collected from }\end{array}$ & $\begin{array}{l}\% \text { Yield } \\
(\% \mathrm{w} / \mathrm{w})\end{array}$ & $\begin{array}{l}\text { Viscosity } \\
\text { (mPa.s) }\end{array}$ & $\begin{array}{l}\text { Specific } \\
\text { Gravity at } 29 \\
{ }^{\circ} \mathrm{C}\end{array}$ & pH & Color \\
\hline C. megalobotrys (Gumare) & $53.74 \pm 0.04$ & $46.0 \pm 3.8$ & $0.894 \pm 0.010$ & $6.53 \pm 0.05$ & $\begin{array}{l}\text { Yellowish- } \\
\text { Brown }\end{array}$ \\
\hline C. megalobotrys (Tumasera) & $47.08 \pm 0.04$ & $45.6 \pm 2.9$ & $0.896 \pm 0.003$ & $6.86 \pm 0.11$ & $\begin{array}{l}\text { Yellowish- } \\
\text { Brown }\end{array}$ \\
\hline C. megalobotrys (Malaka) & $45.21 \pm 0.05$ & $45.2 \pm 3.2$ & $0.898 \pm 0.007$ & $6.89 \pm 0.08$ & $\begin{array}{l}\text { Yellowish- } \\
\text { Brown }\end{array}$ \\
\hline R. cummunis (Gaborone) & $39.65 \pm 0.06$ & $907.0 \pm 17.1$ & $0.942 \pm 0.010$ & $6.88 \pm 0.11$ & $\begin{array}{l}\text { Pale- } \\
\text { Yellow }\end{array}$ \\
\hline R. cummunis (Tumasera) & $44.87 \pm 0.03$ & $987.0 \pm 18.4$ & $0.926 \pm 0.012$ & $6.87 \pm 0.04$ & $\begin{array}{l}\text { Pale- } \\
\text { Yellow }\end{array}$ \\
\hline
\end{tabular}

Phyico-Chemical Properties of the seed-oils

\section{Iodine Value}

The Iodine values in $\mathrm{g}_{2} / 100 \mathrm{~g}$ oil for $R$. cummunis seed-oil was found to be $93.57 \pm 1.00$ and $89.22 \pm$ 1.12 for the seeds collected from Gaborone and Tumasera, respectively. For C. megalobotrys seedoil the Iodine values were $96.51 \pm 1.31,85.97 \pm$ 1.62 , and $91.63 \pm 1.01$ for the seeds collected from Gumare, Tumasera, and Malaka respectively (Table 4 ). These values indicate that the amount of Iodine needed to add to the multiple bonds of the fatty acids in the seed oils is low which means that the level of unsaturation is low in all seed oils studied. Therefore, $R$. cummunis and $C$. megalobotrys seedoils can be regarded as non-drying oils since their iodine values are less than 100 which means they will not harden when exposed to air. Oils with low Iodine values are normally good feedstocks for hydraulic brake fluids and lubricants (Yeboah et al., 2020).

\section{Acid Value}

The acid value in $\mathrm{mg} \mathrm{KOH} / \mathrm{g}$ for $R$. cummunis seedoil was found to be $0.96 \pm 0.05$ and $1.02 \pm 0.03$ for the seeds collected from Gaborone and Tumasera respectively. The low acid values determined for both seed oils indicate that the triacylglycerols have not been hydrolyzed, which could indicate good stability of the seed oils. On the other hand, the acid values for $C$. megalobotrys seed-oils were $5.31 \pm$ $0.76,4.69 \pm 0.87$, and $4.69 \pm 0.87$ for seeds collected from Gumare, Tumasera, and Malaka villages, respectively. According to the American Society for testing and material (AOAC, 2006), the accepted acid value of edible vegetable oils should not exceed $2 \mathrm{mg} \mathrm{KOH} / \mathrm{g}$ of oil suggested that the high acid value may be due to the delay in seed extraction 
which influenced the lipase enzyme to hydrolyze the triglycerides into free fatty acid (Yeboah et al., 2020). Since this is a non-edible seed oil, the oil could still be useful in the petroleum and cosmetics industries even though its acid value is slightly higher than 2.

\section{Saponification Value}

The saponification value in $\mathrm{mg} \mathrm{KOH} / \mathrm{g}$ for $R$. cummunis seed-oil was found to be $139.65 \pm 1.06$ and $141.97 \pm 1.55$ for the seeds obtained from Gaborone and Tumasera respectively. For $C$. megalobotrys seed-oils, the saponification values were $153.01 \pm 1.67,140.09 \pm 1.81$, and $145.21 \pm$ 1.75 for seeds collected from Gumare, Tumasera, and Malaka respectively (Table 4). The saponification values for these oils are significantly high which implies that these seed oils contain high molecular weight triglycerides which confirm their suitability and useful applications for the manufacture of soaps and cosmetic products (Omari et al., 2015).

\section{Peroxide Value}

The peroxide value determination was conducted two to three weeks after the extraction of the oils. During this time the seed oils were kept in screwcapped transparent glass containers. The peroxide values in meq $/ \mathrm{Kg}$ for $R$. cummunis seed oils were found to be $2.04 \pm 0.03$ and $2.11 \pm 0.07$ for the seeds obtained from Gaborone and Tumasera respectively. For $C$. megalobotrys seed-oils, the peroxide values were $0.34 \pm 0.01,0.18 \pm 0.01$, and $0.21 \pm 0.01$ for seeds collected from Gumare, Tumasera, and Malaka respectively (Table 4). These values are very low and show that the seed oils have very low oxidative rancidity which means they can remain in storage for a long time with the negligible change to the seed oil identity.

Table 4: Physico-Chemical Properties of C. megalobotrys and R. cummunis oils obtained from seeds collected at different places in Botswana

\begin{tabular}{|c|c|c|c|c|}
\hline $\begin{array}{l}\text { Oil Name and places seeds } \\
\text { were collected from }\end{array}$ & $\begin{array}{l}\text { Saponification } \\
\text { Value } \mathrm{mg} \mathrm{KOH} / \mathrm{g}\end{array}$ & $\begin{array}{l}\text { Iodine Value } \\
\mathrm{g} \mathrm{I}_{2} / 100 \mathrm{~g}\end{array}$ & $\begin{array}{l}\text { Acid Value } \\
\mathrm{mg} \mathrm{KOH} / \mathrm{g}\end{array}$ & $\begin{array}{l}\text { Peroxide Value } \\
\text { meq } \mathrm{O}_{2} / \mathrm{Kg}\end{array}$ \\
\hline C. megalobotrys (Gumare) & $153.01 \pm 1.67$ & $96.51 \pm 1.31$ & $5.31 \pm 0.76$ & $0.34 \pm 0.01$ \\
\hline C. megalobotrys (Tumasera) & $140.09 \pm 1.81$ & $85.97 \pm 1.62$ & $4.69 \pm 0.87$ & $0.18 \pm 0.01$ \\
\hline C. megalobotrys (Malaka) & $145.21 \pm 1.75$ & $91.63 \pm 1.01$ & $4.71 \pm 0.31$ & $0.21 \pm 0.01$ \\
\hline R. cummunis (Gaborone) & $139.65 \pm 1.06$ & $93.57 \pm 1.00$ & $0.96 \pm 0.05$ & $2.04 \pm 0.03$ \\
\hline R. cummunis (Tumasera) & $141.97 \pm 1.55$ & $89.22 \pm 1.12$ & $1.02 \pm 0.03$ & $2.11 \pm 0.07$ \\
\hline
\end{tabular}

Fatty Acid Composition Using Gas Chromatography-Mass Spectroscopy (GC-MS)

\section{R. cummunis}

Eight peaks were found in the GC-MS spectra belonging to R. cummunis seed-oil (Figure 6, Table 5). The detected components' mass spectra were matched with mass spectra within the reference spectra in NIST 98 Mass Spectral Library and the abundance of the fatty acids identified was calculated. The most abundant fatty acid within the seed-oil was Ricinoleic Acid (Methyl-12-hydroxy9-octadecenoate) at $81.51 \%$ followed by Linoleic acid $(9,12$-Octadecadienoic acid $(\mathrm{Z}, \mathrm{Z}))$ at $6.74 \%$, Oleic acid (9-octadecanoic acid) at $3.43 \%$, Palmatic Acid (Hexadecanoic acid, methyl ester) at $2.32 \%$,
3-Eicosene at $2.06 \%, 1,2$-Octadecanediol at 1.54 $\%, 2$-Ethylnon-1-en-3-ol at $1.44 \%$ and lastly 1Hexadecanol, 2-methyl at $0.96 \%$ (Table 5).

The results show that $R$. cummunis seed-oil contains Ricinoleic acid $(\mathrm{C} 18: 1-\mathrm{OH})$, a monounsaturated fatty acid as the major component of the seed-oil. This is consistent with what has been discovered by others (Omohu \& Omale, 2017; Yeboah et al., 2020). Ricinoleic acid is the main hydroxy fatty acid used in the oleochemical industry because it can undergo a wide range of reactions enabling the formation of several derivatives (Parekh et al., 2011). All other fatty acids are found in negligible amounts to have any meaningful effect on the property of the seed oils (Table 5). 
Figure 6: GC-MS spectrum of R. cummunis oil from seeds collected from Tumasera Village

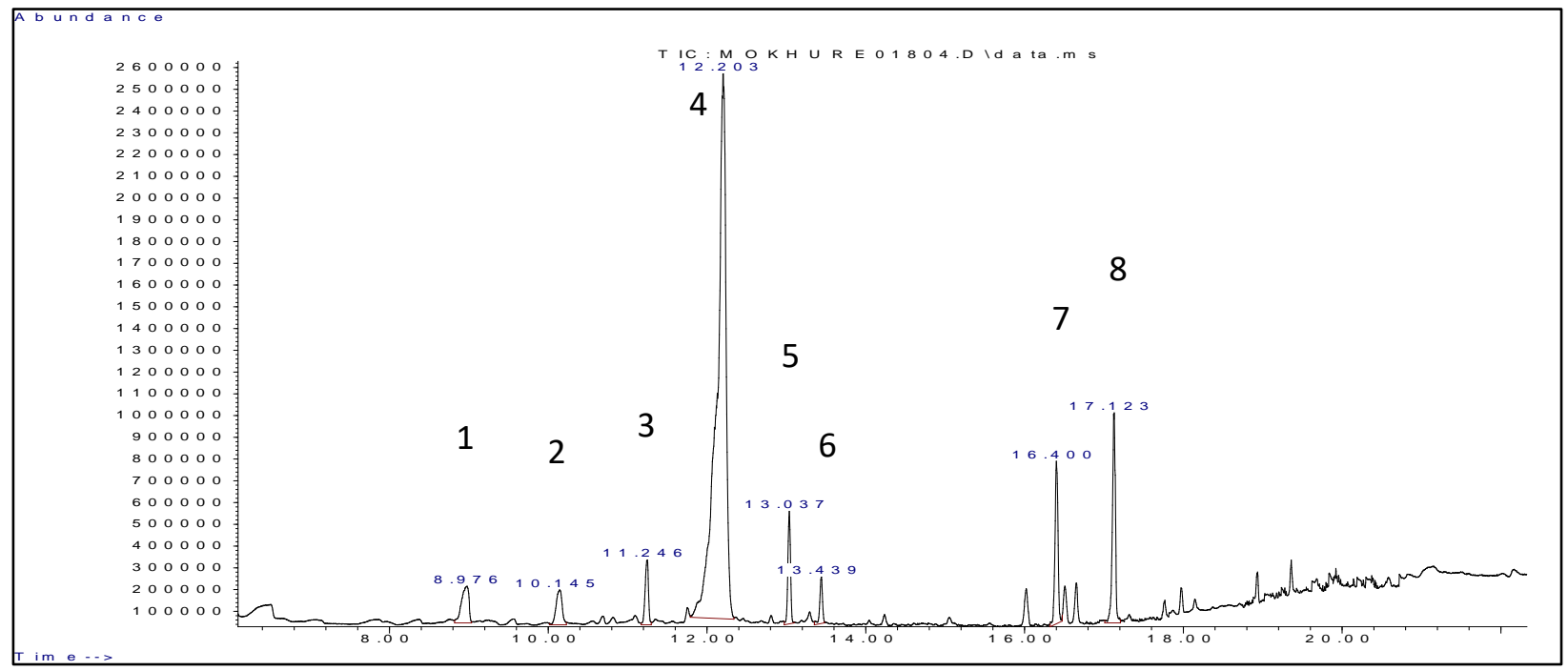

Table 5: Fatty Acid Composition of $R$. cummunis oil from seeds collected from Tumasera Village

\begin{tabular}{llll}
\hline $\begin{array}{l}\text { Peak No } \\
\text { (Figure 6) }\end{array}$ & $\begin{array}{l}\text { Retention } \\
\text { Time (min) }\end{array}$ & Fatty Acid & \% Abundance \\
\hline 1 & 8.98 & 1,2-Octadecanediol & $1.54 \%$ \\
2 & 10.15 & 2-Ethylnon-1-en-3-ol & $1.44 \%$ \\
3 & 11.25 & 3-Eicosene & $2.06 \%$ \\
4 & 12.20 & Methyl-12-hydroxy-9-octadecenoate (Ricinoleic Acid) & $81.51 \%$ \\
5 & 13.04 & Hexadecanoic acid, methyl ester (Palmatic Acid) & $2.32 \%$ \\
6 & 13.44 & 1-Hexadecanol,2-methyl & $0.96 \%$ \\
7 & 16.40 & 9-octadecanoic acid (Oleic acid) & $3.43 \%$ \\
8 & 17.12 & 9,12-Octadecadienoic acid $(\mathrm{Z}, \mathrm{Z})$ (Linoleic acid) & $6.74 \%$ \\
\hline
\end{tabular}

\section{C. megalobotrys}

Five peaks were found in the GC-MS spectra belonging to $C$. megalobotrys seed-oil (Figure 7 and Table 6). The most abundant fatty acid within the seed-oil was Linoleic acid $(9,12-$ Octadecadienoic acid $(\mathrm{Z}, \mathrm{Z}))$ at $58.01 \%$ followed by Palmatic Acid (Hexadecanoic acid, methyl ester) at $19.51 \%$, Oleic acid (9-octadecanoic acid) at $18.37 \%$, Methyl stearate at $2.96 \%$ and finally Methyl tetradecanoate at $1.16 \%$. C. megalobotrys seed-oil contains fewer fatty acids methyl esters compared to $R$. cummunis seed oil, but the most abundant Fatty acid (Linoleic acid) makes just above half of the seed oil. Linoleic acid helps strengthen the skin's barrier so it can effectively keep water in and irritants out. Oils that are rich in linoleic acid prevent the overproduction of oleic acid, therefore balancing sebum production and oiliness that is associated with acne-prone skin. In some cases, just rubbing a small amount of linoleic acid on mild acne can reduce the size of pimples. On top of that, it is used to treat other skin concerns such as dryness, dehydration, pigmentation, and sensitivity (Liddle, 2021).

The other two fatty acids with significant quantities are palmitic acid and oleic acid. Palmitic acid is used to produce soaps, cosmetics, and industrial mold release agents. These applications use sodium palmitate, which is commonly obtained by saponification of Palmitic acid containing seed oil such as palm oil (May and Nesaretnam, 2014). Oleic acid is a major component of soap as an emulsifying agent. It is also used as an emollient (moisturizer). Small amounts of oleic acid are used as an excipient in pharmaceuticals, and it is used as an emulsifying 
or solubilizing agent in aerosol products (Susan, 1992).

Figure 7: GC-MS spectrum of $C$. megalobotrys oil from seeds collected from Tumasera Village

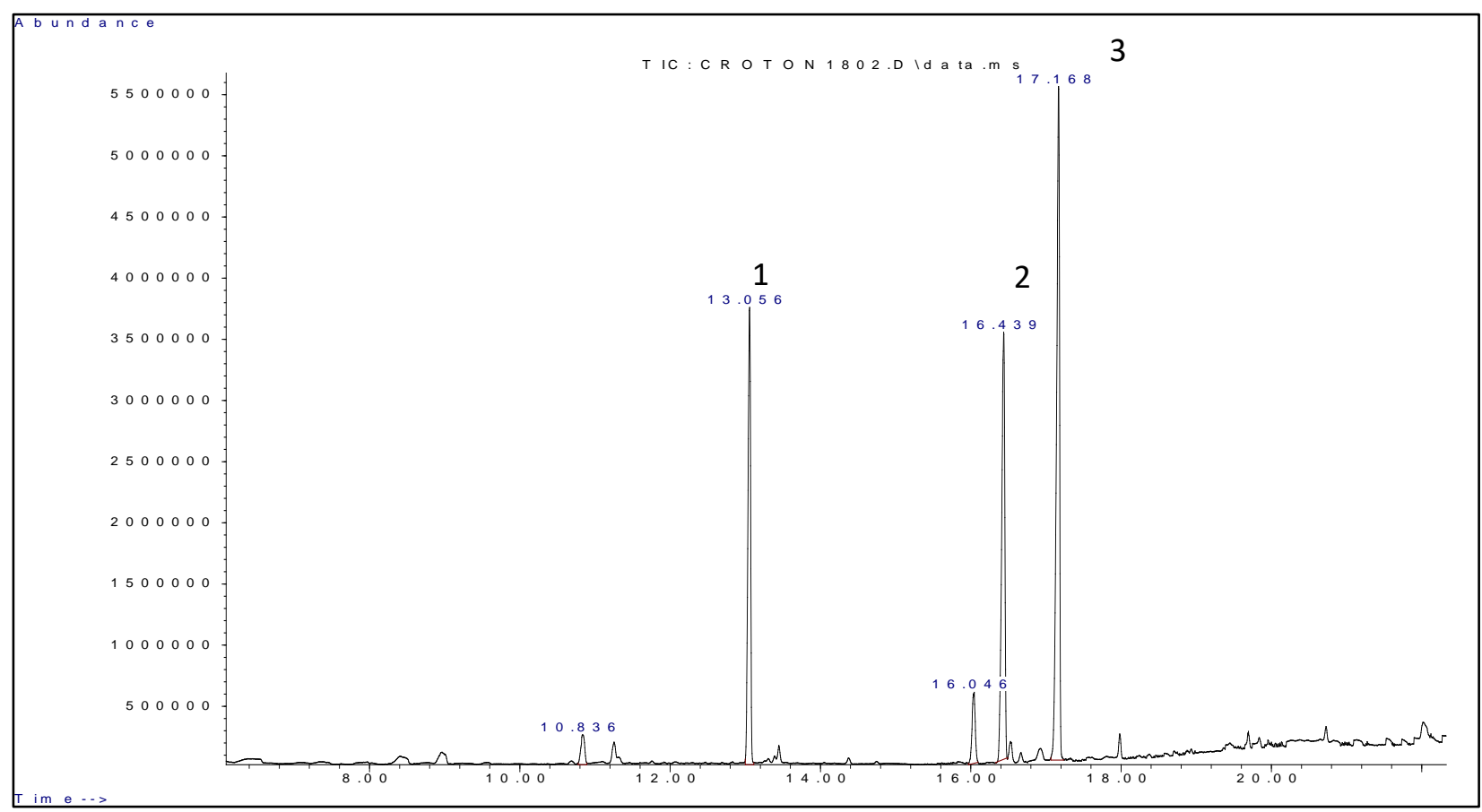

Table 6: Fatty Acid Composition of $C$. megalobotrys oil from seeds collected from Tumasera Village

\begin{tabular}{llll}
\hline $\begin{array}{l}\text { Peak No } \\
\text { (Figure 7) }\end{array}$ & $\begin{array}{l}\text { Retention } \\
\text { Time (min) }\end{array}$ & Fatty Acid & \% Abundance \\
\hline 1 & 10.84 & Methyl tetradecanoate & $1.16 \%$ \\
2 & 13.05 & Hexadecanoic acid, metthyl ester (Palmatic Acid) & $19.51 \%$ \\
3 & 16.05 & Methyl stearate & $2.96 \%$ \\
4 & 16.44 & 9-octadecanoic acid (Oleic acid) & $18.37 \%$ \\
5 & 17.17 & $9,12-$ Octadecadienoic acid $(\mathrm{Z}, \mathrm{Z})($ Linoleic acid) & $58.01 \%$ \\
\hline
\end{tabular}

Qualitative Analysis of The Oils Using UV-Vis and FT-IR Spectrophotometry

\section{UV-Vis Analysis}

Figures 8 and 9 show the UV-Vis spectra of seed oils of $R$. cummunis and $C$. megalobotrys respectively. The two seed oils absorb between 290 $\mathrm{nm}$ and $320 \mathrm{~nm}$ which is the ultraviolet (UV) region of the electromagnetic spectrum. This shows that the two oils if used on cosmetic products, can protect the skin against UV rays. The two oils can therefore be good feedstocks in the production of sunscreen creams and lotions. 
Figure 8: UV-Vis spectrum of $R$. cummunis oil from seeds collected from Tumasera Village

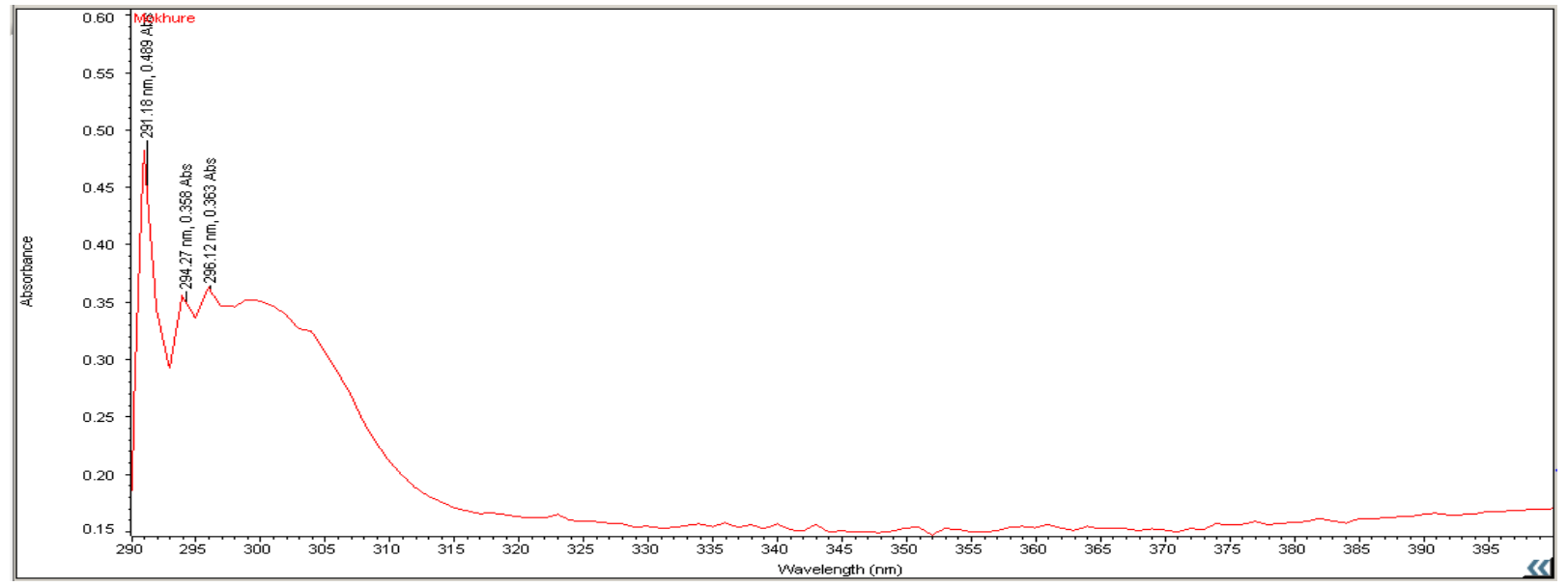

Figure 9: UV-Vis spectrum of C. megalobotrys oil from seeds collected from Tumasera Village

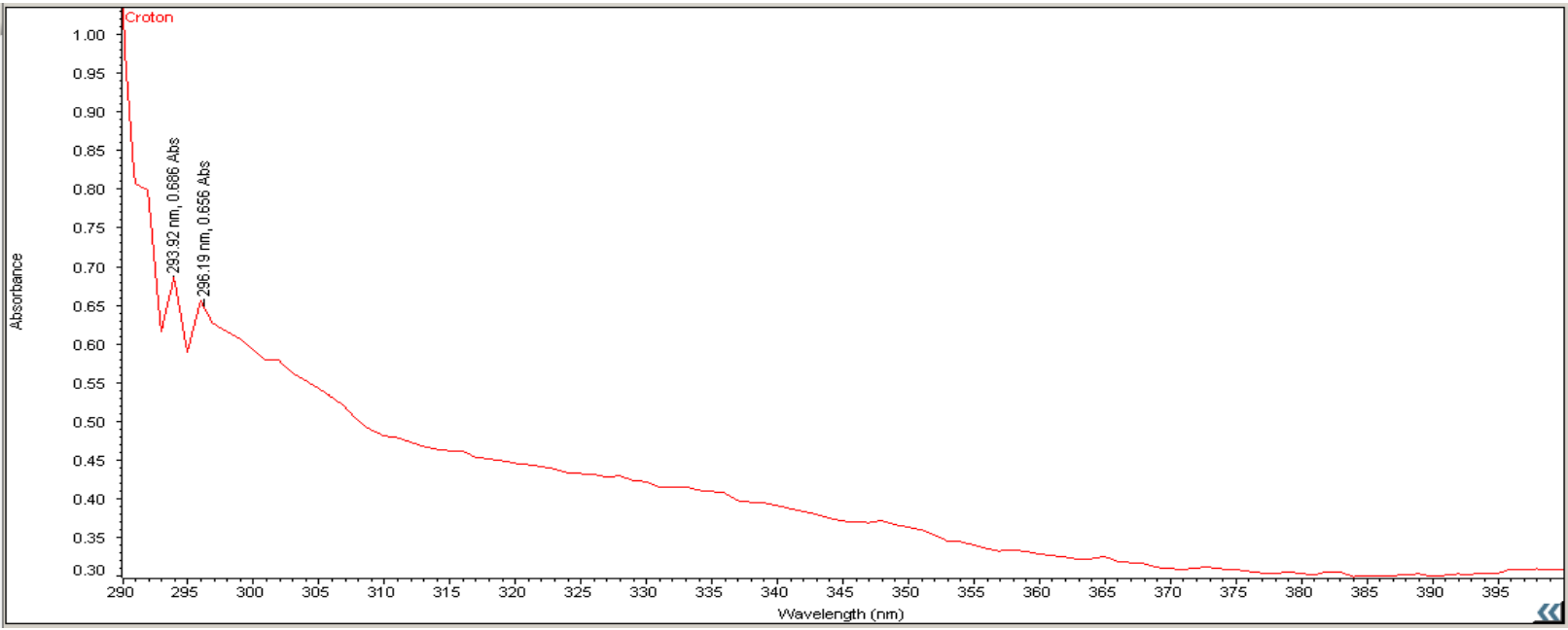

\section{Fourier Transform Infrared (FTIR) Spectrophotometric Analysis}

Figures 10 and 11 show the FTIR spectra of seed oils of $R$. cummunis and $C$. megalobotrys respectively. The spectra show similar peaks even though the oils are made from different fatty acids. There are C-H stretching vibration peak at 2923.9 $\mathrm{cm}^{-1}$ and $2852.5(2855.5) \mathrm{cm}^{-1}, \mathrm{C}=\mathrm{O}$ stretching vibration peak at $1743.7 \mathrm{~cm}^{-1}$, the bending vibration peak of methylene at $1461.3 \mathrm{~cm}^{-1}$, the carbon skeleton vibration peak at $724.0(721.1) \mathrm{cm}^{-1}$, the stretching vibration peak of $\mathrm{C}-\mathrm{O}$ in the triglyceride at $1161.3(1161.0) \mathrm{cm}^{-1}$ and olefin reflector outside stretching vibration peaks at $1098.6(1095.6) \mathrm{cm}^{-1}$. The spectrums of the peak position and peak shape are similar; therefore, the main components of different fatty acids are similar in these two seed oils. This is like what was observed by other researchers on different kinds of seed oils (Shi et al., 2017). 
Figure 10: FTIR spectrum of $R$. cummunis oil from seeds collected from Tumasera Village

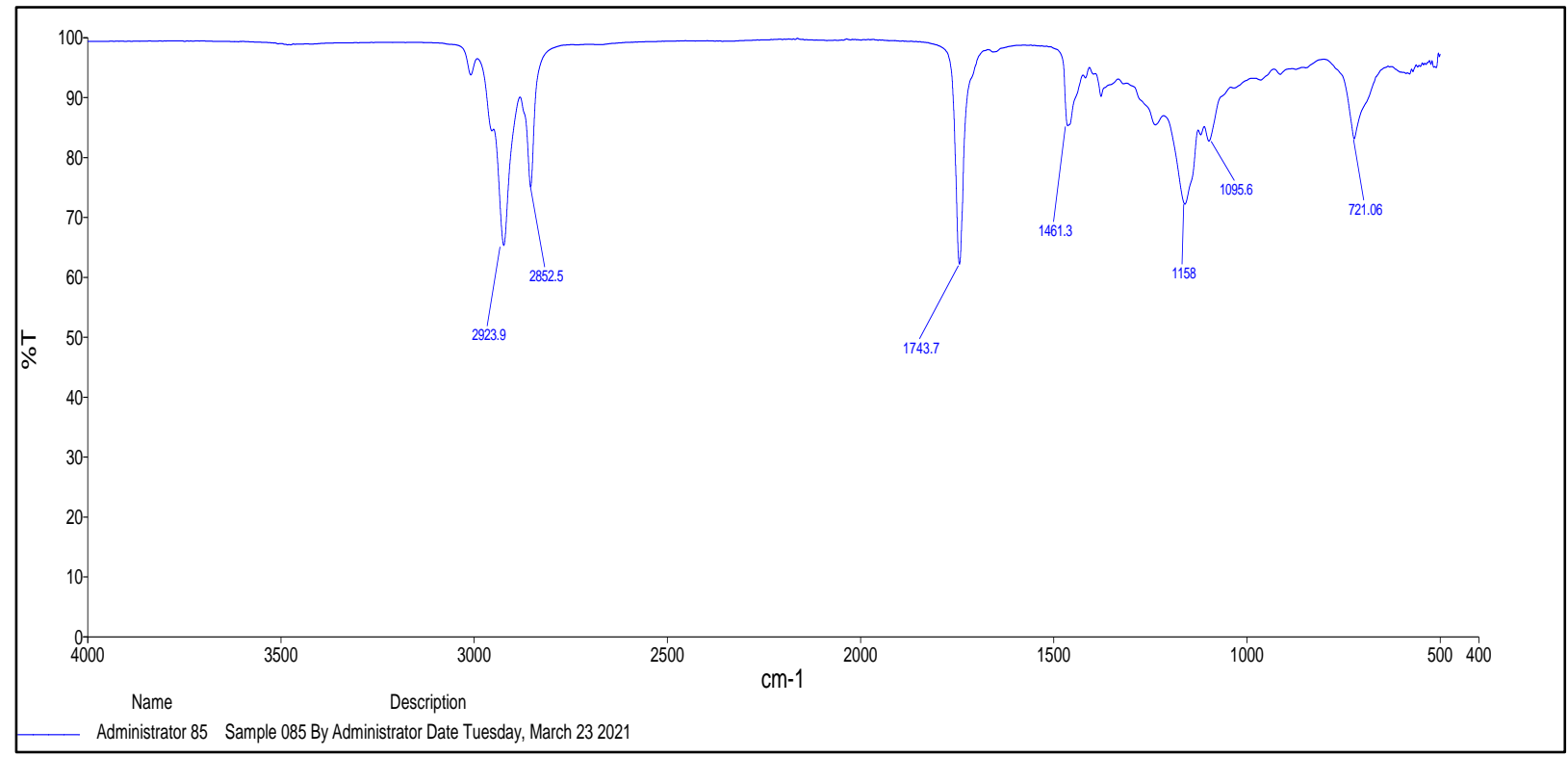

Figure 11: FTIR spectrum of $C$. megalobotrys oil from seeds collected from Tumasera Village

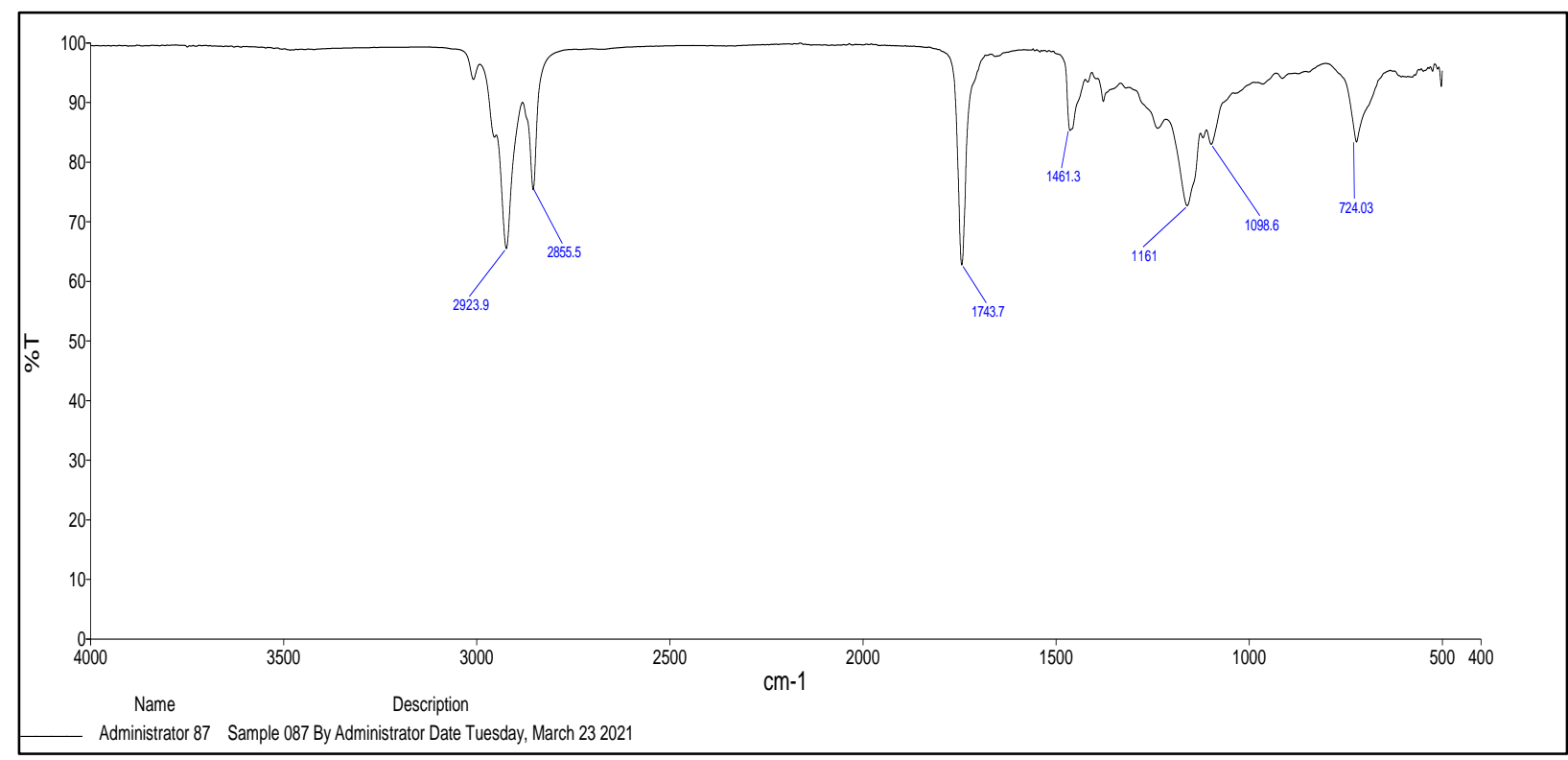

\section{CONCLUSION}

This study shows that Botswana wild $C$. megalobotrys (Motsebi/Letsebi/Moshoole) and $R$. cummunis (Mokhure) plants produce high-quality non-edible seed oils at relatively high quantities of $45.21 \pm 0.05 \% \mathrm{w} / \mathrm{w}$ to $53.74 \pm 0.04 \% \mathrm{w} / \mathrm{w}$ and $39.65 \pm 0.06 \% \mathrm{w} / \mathrm{w}$ to $44.87 \pm 0.03 \% \mathrm{w} / \mathrm{w}$ respectively. The Iodine values of $85.97 \pm 1.62 \mathrm{~g}$ $\mathrm{I}_{2} / 100 \mathrm{~g}$ to $96.51 \pm 1.31 \mathrm{~g} \mathrm{I}_{2} / 100 \mathrm{~g}$ for both plants show that these non-drying seed oils can be good feedstocks for hydraulic brake fluids and lubricant industries. The low acid values for these seed oils of $0.96 \pm 0.05 \mathrm{mg} \mathrm{KOH} / \mathrm{g}$ to $5.31 \pm 0.76 \mathrm{mg} \mathrm{KOH} / \mathrm{g}$ and high saponification values of $139.65 \pm 1.06 \mathrm{mg}$ $\mathrm{KOH} / \mathrm{g}$ to $153.01 \pm 1.67 \mathrm{mg} \mathrm{KOH} / \mathrm{g}$ shows that these seed oils can be useful feedstocks in the petroleum, soap, and cosmetics industries. The low Peroxide values of $0.18 \pm 0.01 \mathrm{meq} \mathrm{O}_{2} / \mathrm{Kg}$ to $2.11 \pm$ 0.07 meq $\mathrm{O}_{2} / \mathrm{Kg}$ affirms that these seed oils are very 
stable and can be stored for a long time without undergoing any significant oxidative rancidity.

R. cummunis seed oil GC-MS spectrum showed that the seed oil is made up of eight (8) fatty acids with the bulk of the seed oil being ricinoleic acid (C18:1$\mathrm{OH})$ at $81.51 \%$. This means that the properties of $R$. cummunis seed oil is dependent on the properties of ricinoleic acid. Ricinoleic acid is the main fatty acid used in oleochemical industries because it undergoes a wide variety of reactions leading to the formation of several derivatives. That is why $R$. cummunis (Castor plant) seed oil has been used as feedstock in the preparation of more than 700 products around the world.

On the other hand, C. megalobotrys seed oil GC-MS spectrum showed that the seed oil is made up of five (5) fatty acids with Linoleic acid being the most abundant fatty acid making up $58.01 \%$ of the seed oil. Linoleic acid is known to help strengthen the human skin's barrier helping the skin to effectively keep the water in and irritants out. It is also known to be effective in preventing acne, pimples, and most other skin problems. The other two significant fatty acids in this seed oil are palmitic and oleic acids at $19.51 \%$ and $18.37 \%$ respectively. These acids are important as starting materials in soap, cosmetic, and pharmaceutical industries.

The UV-Vis spectra of the two seed oils show that their fatty acids absorb light at the ultraviolet region of the electromagnetic spectrum. This means that cosmetic products made from these seed oils will be effective in protecting the human skin against ultraviolet radiation. The FT-IR peaks for these two seed oils show that even though these seed oils are made up of different fatty acids, the active sites of their fatty acids are similar. This implies that these seed oils can be used as starting materials in almost the same industries. Botswana should therefore start utilizing these seed oils to start and grow its cosmetic and green petroleum industries. This should start with protecting these two plants from extinction and encouraging arable farmers to start growing these plants as cash crops for export to cosmetic and green petroleum companies around the world.

\section{Authorship Contribution Statement}

Banyaladzi Doctor Paphane: Investigation, validation, formal analysis, and writing of the original Draft

Bonang Nkoane: Resource mobilization, writing (review and editing), and supervision

Olanyika Oyetunji: Resource mobilization, writing (review and editing), and supervision

\section{Declaration of Competing Interest}

The authors declare that they have no known competing financial interests or personal relationships that could have appeared to influence the work reported in this paper

\section{ACKNOWLEDGMENT}

We are thankful to the Department of Chemistry, University of Botswana and the Department of Physical and Chemical Sciences, Botswana University of Agriculture and Natural Resources for funding this work.

\section{REFERENCES}

Anjani, K. (2014). A re-evaluation of castor (Ricinus communis L.) as a crop plant. $C A B$ Reviews, 9, 38

AOAC, 2006. Official Methods of Analysis of AOAC International, 18th ed. Association of Official Analytical Chemists, Washington, DC.

Asong, J. A., Ndhlovu, P. T., Khosana, N. S., Aremu, A. O., \& Otang-Mbeng, W. (2019). Medicinal plants used for skin-related diseases among the Batswanas in Ngaka Modiri Molema District Municipality, South Africa. South African journal of botany, 126, 11-20.

Bokhari, A., Chuah, L. F., Yusup, S., Ahmad, J., \& Aziz, H. (2015). Kapok seed oil extraction using soxhlet extraction method: optimization and parametric study. Australian Journal of Basic and Applied Sciences, 9(37), 429-431.

Chinsembu, K. C., Syakalima, M., \& Semenya, S. S. (2019). Ethnomedicinal plants used by traditional healers in the management of 
HIV/AIDS opportunistic diseases in Lusaka, Zambia. South African Journal of Botany, 122, 369-384.

Franke, H., Scholl, R., \& Aigner, A. (2019). Ricin and Ricinus communis in pharmacology and toxicology-from ancient use and "Papyrus Ebers" to modern perspectives and "poisonous plant of the year 2018". Naunyn-Schmiedeberg's archives of pharmacology, 392(10), 1181-1208.

Gabalebatse, M., Ngwenya, B. N., Teketay, D., \& Kolawole, O. D. (2013). Ethno-veterinary practices amongst livestock farmers in Ngamiland District, Botswana. African Journal of Traditional, Complementary and Alternative Medicines, 10(3), 490-502.

Gatonye, Tietjen, I., T., Ngwenya, B. N., Namushe, A., Simonambanga, S., Muzila, M., ... \& Andrae-Marobela, K. (2016). Croton megalobotrys Müll Arg. and Vitex doniana (Sweet): Traditional medicinal plants in a threestep treatment regimen that inhibit in vitro replication of HIV-1.Journal of ethnopharmacology, 191, 331-340.

Hedberg, I., \& Staugård, F. (1989). Traditional medicinal plants (Vol. 3). Ipelegeng Publishers.

Heikal, E. K., Elmelawy, M. S., Khalil, S. A., \& Elbasuny, N. M. (2017). Manufacturing of environment friendly biolubricants from vegetable oils. Egyptian Journal of Petroleum, 26(1), 53-59.

Ichihara, K. I., \& Fukubayashi, Y. (2010). Preparation of fatty acid methyl esters for gasliquid chromatography [S]. Journal of lipid research, 51(3), 635-640.

Kružlicová, D., Mocak, J., Katsoyannos, E., \& Lankmayr, E. (2008). Classification and characterization of olive oils by UV-Vis absorption spectrometry and sensorial analysis. Journal of Food \& Nutrition Research, 47(4).

Kubala, J. (2018). 7 Benefits and uses of castor oil Castor Oils. https://www.healthline.com/nutriti on/castor-oil
Langat, M. K., Djuidje, E. F., Ndunda, B. M., Isyaka, S. M., Dolan, N. S., Ettridge, G. D., ... \& Kamdem, A. F. (2020). The phytochemical investigation of five African Croton species: Croton oligandrus, Croton megalocarpus, Croton menyharthii, Croton rivularis and Croton megalobotrys. Phytochemistry Letters, 40, 148155.

Liddle, H. (2021). Linoleic acid in skin care. https://www.cosmetify.com/us/linoleic- acid- in - skin-care/

Maroyi, A. (2017). Ethnomedicinal uses and pharmacological activities of Croton megalobotrys Müll Arg: A systematic review. Tropical Journal of Pharmaceutical Research, 16(10), 2535-2543.

Marwat, S., Khan, E. A., Baloch, M. S., Sadiq, M., Ullah, I., Javaria, S., \& Shaheen, S. (2017). Ricinus cmmunis: Ethnomedicinal uses and pharmacological activities. Pakistan journal of pharmaceutical sciences, 30(5).

May, C. Y., \& Nesaretnam, K. (2014). Research advancements in palm oil nutrition. European journal of lipid science and technology, 116(10), 1301-1315.

Mubofu, E. B. (2016). Castor oil as a potential renewable resource for the production of functional materials. Sustainable Chemical Processes, 4(1), 1-12.

Neelo, J., Kashe, K., Teketay, D., \& Masamba, W. (2015). Ethnobotanical survey of woody plants in Shorobe and Xobe villages, northwest region of Botswana. Ethnobotany Research and Applications, 14, 367-379.

Omahu, O. J., \& Omale, A. C. (2017). Physicochemical properties and fatty acid composition of castor bean Ricinus communis L. seed oil. American Journal of Applied and Industrial Chemistry, 3(1), 1-4.

Omari, A., Mgani, Q. A., \& Mubofu, E. B., 2015. Fatty acid profile and physico-chemical parameters of castor oils in Tanzania. Green and Sustainable Chemistry, 5(4), 154-163. 
Panhwar, T., Mahesar, S. A., Mahesar, A. W., Kandhro, A. A., Talpur, F. N., Laghari, Z. H., ... \& Sherazi, S. T. H. (2016). Characteristics and composition of a high oil yielding castor variety from Pakistan. Journal of oleo science, 65(6), 471-476.

Parekh, V. J., Rathod, V. K., \& Pandit, A. B. (2011). Substrate hydrolysis: Methods, mechanism, and industrial applications of substrate hydrolysis.

Sarasan, G., \& Rangwala, J. A. (2014). Synthesis of soap from non-edible oils and a comparative study of quality parameters. International Journal of Chemical Sciences, 12(1), 306-314.

Sejkorová, M., Šarkan, B., Veselík, P., \& Hurtová, I. (2020). FTIR Spectrometry with PLS Regression for Rapid TBN Determination of Worn Mineral Engine Oils. Energies, 13(23), 6438 .

Semenya, S. S., \& Maroyi, A. (2019). Ethnobotanical survey of plants used by Bapedi traditional healers to treat tuberculosis and its opportunistic infections in the Limpopo Province, South Africa. South African Journal of Botany, 122, 401-421.

Setshogo, M., \& Fenter, F. (2003). Trees of Botswana: names and distribution. Southern African Botanical Diversity Network Report No. 18. Pretoria, Southern African Botanical Diversity Network (SABONET).

Shi, L., Liu, Z., Li, J., \& Qin, Z. (2017). Analysis of edible vegetable oils by infrared absorption spectrometry. Advances in Engineering Research, 86, 286-289.
Shikha, K., \& Chauhan, Y. R. (2012). Biodiesel production from non- edible- oils: a review. Jou rnal of Chemical and Pharmaceutical Research, 4(9), 4219-4230.

Susan, C. (1992). Handbook of food, drug, and cosmetic excipients. American Journal of Clinical Nutrition, 73(1), 41-44.

UN, U. (2017). Department of Economic and Social Affairs. Population Division.

Venter, F., \& Venter, J. A. (2007). Making the most of indigenous trees. Briza publications.

World Population Growth, (2021). Projections of population growth. https://en.wikipedia.org/wiki/Projections_of_po pulation_growth, searched on the $11^{\text {th }}$ of June 2021

Yaşar, F. (2020). Comparision of fuel properties of biodiesel fuels produced from different oils to determine the most suitable feedstock type. Fuel, 264, 116817.

Yeboah, A., Ying, S., Lu, J., Xie, Y., AmoanimaaDede, H., Boateng, K. G. A., ... \& Yin, $X$. (2020). Castor oil (Ricinus communis): a review on the chemical composition and physicochemical properties. Food Science and Technology.

Yuenyong, J., Pokkanta, P., Phuangsaijai, N., Kittiwachana, S., Mahatheeranont, S., \& Sookwong, P. (2021). GC-MS and HPLC-DAD analysis of fatty acid profile and functional phytochemicals in fifty cold-pressed plant oils in Thailand. Heliyon, 7(2), e06304. 